\title{
Differences in meat colour between free-range Swallow Belly Mangalitsa and commercially reared Swedish Landrace pigs during 6 days of vacuum storage
}

\author{
Nikola Stanišić ${ }^{1}$, Nenad Parunovićc ${ }^{2}$, Slaviša Stajićc ${ }^{3}$, Milica Petrović ${ }^{3}$, Čedomir Radović ${ }^{1}$, \\ Dušan Živković ${ }^{3}$, and Maja Petričević ${ }^{1}$ \\ ${ }^{1}$ Institute for Animal Husbandry, Autoput 16, 11080 Belgrade, Serbia \\ ${ }^{2}$ Institute of Meat Hygiene and Technology, Kaćanskog 13, 11000 Belgrade, Serbia \\ ${ }^{3}$ University of Belgrade, Faculty of Agriculture, Nemanjina 6, 11080 Belgrade, Serbia
}

Correspondence to: Nikola Stanišić (nikola0135@yahoo.com)

Received: 13 January 2016 - Revised: 7 March 2016 - Accepted: 18 March 2016 - Published: 1 April 2016

\begin{abstract}
The influence of storage on meat colour differences between free-range Swallow Belly Mangalitsa (MA, $n=19$ ) and commercially reared Swedish Landrace (SL, $n=17$ ) pigs, are investigated in the present study. Proximate composition analyses were done on fresh samples of M. longissimus thoracis (LT) and M. gluteus medius (GM), while $\mathrm{pH}$ values and colour quality attributes were determined on fresh cuts of the muscles (day 1) and after 3 and 6 days of vacuum storage at $4 \pm 1{ }^{\circ} \mathrm{C}$. MA pork had a significantly higher share of intramuscular fat, a darker colour, a higher deoxymyoglobin $(\mathrm{Mb})$ content and oxy / met (oxymyoglobin / metmyoglobin) ratio, higher $\mathrm{pH}_{24} \mathrm{~h}$ values and a slower $\mathrm{pH}$ decline compared to the control SL group $(P<0.05)$. Greater changes in myoglobin forms during storage were observed in MA pork, which were reflected in a significant decrease in the content of $\mathrm{Mb}$ and an increase in the oxy / met ratio $(P<0.05)$.

After 6 days of vacuum storage, higher $\mathrm{pH}_{6 \mathrm{~d}}$ values, a lower metmyoglobin (MetMb) content and a higher oxy / met ratio of MA pork lead to the conclusion that aged meat from free-range Swallow Belly Mangalitsa pigs had better colour quality compared to Swedish Landrace pigs.
\end{abstract}

1

\section{Introduction}

The discoloration of fresh meat, one of the most important concerns in the pork industry, is determined by the relative concentration of the three redox forms of myoglobin: deoxymyoglobin $(\mathrm{Mb})$, oxymyoglobin $\left(\mathrm{MbO}_{2}\right)$ and metmyoglobin (MetMb) (Ledward, 1992). The three pigments can be changed from one to the other, depending on the conditions at which the meat is stored and on $\mathrm{pH}$ and temperature (Brewer et al., 2001; Mancini and Hunt, 2005; Lindahl et al., 2006). As consumers use meat colour as an evidence of freshness and quality at the moment of purchase, the loss in economic value that follows fresh meat discoloration can be substantial (Sales and Koukolová, 2011).
The colour of pork measured $24 \mathrm{~h}$ post mortem is commonly included in research, but colour stability during storage is less frequently studied. Storage of pork post mortem is reported to influence the colour (Schluter et al., 1994; Apple et al., 2001, 2002; Rosenvold and Andersen, 2003; Frederick et al., 2004) and the ability of pork to bloom (Zhu et al., 2001). However, the majority of studies investigating the effects of storage and $\mathrm{pH}$ on pork colour have been focused on modern meat-type breeds of pigs (Edwards et al., 2003; Brewer et al., 2004) that are reared in an intensive pig farming system, which is considered to compromise the welfare of the pigs (Barton-Gade, 2002). Recently, there has been a larger commercial interest in the pork products originating from natural animal production systems, e.g. freerange products (Kijlstra et al., 2009). A successful free-range 
production system requires producers to have suitable pig breeds, such as autochthonous breeds (Miao et al., 2004). In the Republic of Serbia three native autochthonous pig breeds are registered: Swallow Belly Mangalitsa, Moravka and Resavka. They are recorded in the domestic animal diversity information system (DAD-IS, 2015). Swallow Belly Mangalitsa is the most prevalent (Petrović et al., 2010), and it is primarily reared in the northern part of the country. There are also considerable populations of Mangalitsa in Hungary, Switzerland, Germany and Austria and some in Romania and in other areas of the former Yugoslavia (Putnam, 1991; Egerszegi et al., 2003). In Serbia, there are three varieties: White (Blond), Swallow Belly and Red Mangalitsa (Egerszegi et al., 2003; Petrović et al., 2010; DAD-IS, 2015). It is a typical fat-type pig which contains approx. $30-35 \%$ of meat in the carcass sides (Egerszegi et al., 2003; Petrović et al., 2009).

Several studies have shown the colour characteristics of Swallow Belly Mangalitsa pigs (Stanišić et al., 2013; Tomović et al., 2014). However, no studies on the effect of storage on colour and colour stability of pork from freerange Swallow Belly Mangalitsa pigs have previously been reported in the literature. Regarding this, the aim of this study was to determine colour characteristics during 6 days of refrigerator storage of vacuum-packed M. longissimus thoracis and M. gluteus medius from free-range Swallow Belly Mangalitsa compared to commercially reared Swedish Landrace pigs. The swallow-bellied Mangalitsa breed was selected as autochthonous Serbian pig breed, while Swedish Landrace was chosen as the most common commercial pig breed in Serbia. Data obtained in this research could be very important for predicting the colour stability of free-range pork under different market scenarios.

\section{Material and methods}

\subsection{Pig production, slaughter procedure and muscle sampling}

Two pig genotypes were used (pigs were castrated under anaesthesia after weaning): Swallow Belly Mangalitsa (MA, $n=19$ ) and Swedish Landrace (SL, $n=17$ ). Swallow Belly Mangalitsa pigs were reared in the open system (Bojčin forest, Vojvodina, Serbia: $44^{\circ} 43^{\prime} 41.45^{\prime \prime} \mathrm{N}, 20^{\circ} 09^{\prime} 43.38^{\prime \prime} \mathrm{E}$; $420000 \mathrm{~m}^{2}$ area). The growth and development of Swallow Belly Mangalitsa pigs included different periods from birth to slaughter: from 90 days of age ( 13 to $15 \mathrm{~kg}$ ) they were reared free-range and were fed grass, leaves and acorns, with the addition of a small quantity of corn during winter (Tomović et al., 2014). The pigs from the control group (Swedish Landrace) were raised at the commercial farm in the Institute for Animal Husbandry (Belgrade, Serbia), with a standard grower-finishing diet during the whole experiment until slaughter. Their diet consisted of concentrated commercial feed administered ad libitum (Table 1). Water was pro-
Table 1. Composition of feed used in the fattening of Swedish Landrace pigs.

\begin{tabular}{lrr}
\hline Mixture ingredients (\%) & \multicolumn{2}{c}{ Live weight $(\mathrm{kg})$} \\
\cline { 2 - 3 } & $25-60$ & $60-105$ \\
\hline Corn silage & 63.02 & 68.76 \\
Flour for livestock & 15.00 & 15.00 \\
Soybean meal & 14.00 & 9.10 \\
Sunflower meal & 5.00 & 4.00 \\
Chalk & 1.40 & 1.40 \\
Monocalcium phosphate & 0.60 & 0.70 \\
Sodium chloride & 0.40 & 0.45 \\
Premix a & 0.50 & 0.50 \\
Synthetic lysine & 0.08 & 0.09 \\
\hline Total & 100.00 & 100.00 \\
\hline
\end{tabular}

a Premix consisted of $6.7 \%$ iron, $3.5 \%$ zinc, $1.7 \%$ manganese, $1.70 \%$ copper, $0.2 \%$ iodine, $0.2 \%$ cobalt and $0.2 \%$ selenium; $0.2 \%$ vitamin $\mathrm{A}, 0.1 \%$ vitamin $\mathrm{D} 3,2.4 \%$ vitamin E, $0.04 \%$ vitamin $\mathrm{K} 3,0.04 \%$ vitamin $\mathrm{B} 1,0.06 \%$ vitamin $\mathrm{B} 2,0.03 \%$ vitamin $\mathrm{B} 6,0.03 \%$ vitamin $\mathrm{B} 12,0.30 \%$ niacin, $0.10 \%$ biotin and $16.70 \%$ choline chloride.

vided using automatic feeding troughs. Feed was withdrawn $24 \mathrm{~h}$ before slaughter, during which time the animals had free access to water. All pigs were slaughtered in a commercial slaughterhouse upon reaching their target live weight of $105 \pm 3 \mathrm{~kg}$.

The pigs were electrically stunned, exsanguinated, scalded at $65^{\circ} \mathrm{C}$ for $4 \mathrm{~min}$, cleaned and eviscerated within $30 \mathrm{~min}$. The carcasses were then cut into sides and put in a cooling chamber at a temperature of $2 \pm 1^{\circ} \mathrm{C}$ for the next 24 hours, after which two muscles, Longissimus thoracis (LT) and Gluteus medius (GM), were taken for analyses. The meat samples were trimmed of visible adipose and connective tissue, packed under vacuum in clear plastic, gas-impermeable packaging and stored for up to 6 days at $4 \pm 1{ }^{\circ} \mathrm{C}$. Proximate composition analyses were done on fresh meat samples (after $24 \mathrm{~h}$ of chilling). All pH and colour measurements were done on meat samples before packaging (day 1) and after 3 and 6 days of vacuum storage.

\subsection{Proximate composition}

The proximate composition was determined as follows: moisture content by drying samples at $103 \pm 2{ }^{\circ} \mathrm{C}$ (ISO 1442 , 1997); protein content by the Kjeldahl method and multiplying by a factor of 6.25 (ISO 937, 1978); total fat content by Soxhlet method (ISO 1443, 1973); and ash content by mineralisation of the samples at $550 \pm 25^{\circ} \mathrm{C}$ (ISO 936, 1998).

\subsection{Meat $\mathrm{pH}$}

The $\mathrm{pH}$ value was measured by $\mathrm{pH}$ meter HI 83141 (Hanna Instruments, USA), equipped with an puncture electrode. 
The $\mathrm{pH}$ meter was calibrated using standard phosphate buffers (ISO 2917, 1999).

\subsection{Myoglobin form measurements}

The spectrophotometric reflectance was measured directly on the meat without the covering film after cutting a fresh surface and after blooming for $30 \mathrm{~min}$. The instrument (Specord S600, equipped with integrating sphere, Analytik Jena AG, Germany) measured reflectance at the following wavelengths: 474, 525, 572, 610 and $630 \mathrm{~nm}$; KubelkaMunk $(K / S)$ values were also calculated. The relative content of $\mathrm{Mb}$ was estimated by the ratio $K / S(474 / 525)$, the relative content of $\mathrm{MbO}_{2}$ by the ratio $K / S(610 / 525)$ and the relative content of MetMb by the ratio $K / S(572 / 525)$ (Hunt et al., 1991; Mancini et al., 2003). The oxy / met ratio was calculated by dividing the percentage of light reflectance at $630 \mathrm{~nm}$ by the percentage of light reflectance at $580 \mathrm{~nm}$ (Hunt et al., 1991).

\subsection{Instrumental measurement of colour}

The colour of freshly cut meat surface following $30 \mathrm{~min}$ blooming time (samples were stored in contact with air at $4{ }^{\circ} \mathrm{C}$ ) was measured using a Chroma Meter CR-400 (Minolta Co. Ltd, Tokyo, Japan) configured with the following parameters: D65 light source, $10^{\circ}$ observer and $8 \mathrm{~mm}$ aperture size. It was calibrated using a white ceramic tile. The measurements were done according to the CIE $L * a * b *$ system: lightness $\left(L^{*}\right)$, redness $\left(a^{*}\right)$ and yellowness $\left(b^{*}\right)$ (CIE, 1976). The colour measurements were performed at room temperature $\left(20 \pm 2{ }^{\circ} \mathrm{C}\right.$ ). $C^{*}$ (chroma) and $h$ (hue angle) were calculated using the available software. Three readings were made on non-overlapping areas of the muscles, and the average value was used for data analysis.

\subsection{Statistical analysis}

Before comparing the groups, a Shapiro-Wilk test $(P>0.05)$ showed that the data obtained were approximately normally distributed (Shapiro and Wilk, 1965). In order to determine the effect of breed on the proximate composition of muscles, a Student $t$ test was performed using SPSS 20.0 software (IBM SPSS Statistics, Version 20, IBM Corp., USA). The model used for analysing LT and GM muscle $\mathrm{pH}$ and colour characteristics included the fixed effects of breed and storage time, in relation to which a two-factorial analysis of variance (ANOVA) was performed using the general linear model (GLM) procedure of the above-mentioned software. When the effect of storage was significant, Duncan's test was used to identify the significant differences between groups. Two-way interactions were included when significant. All differences were considered to be significant at $P<0.05$ and data are presented as mean value $\pm \mathrm{SD}$.
Table 2. Differences in proximate composition of LT and GM muscles between Swallow Belly Mangalitsa (MA) and Swedish Landrace (SL) pigs.

\begin{tabular}{|c|c|c|c|}
\hline & MA $(\%)$ & SL $(\%)$ & $P$ value \\
\hline \multicolumn{4}{|c|}{ Longissimus thoracis } \\
\hline Moisture & $70.79 \pm 1.86$ & $72.43 \pm 1.72$ & 0.187 \\
\hline Fat & $5.42 \pm 0.32$ & $1.85 \pm 0.17$ & $<0.001$ \\
\hline Protein & $22.68 \pm 2.93$ & $24.29 \pm 1.71$ & 0.166 \\
\hline Ash & $1.08 \pm 0.07$ & $1.13 \pm 0.09$ & 0.118 \\
\hline \multicolumn{4}{|c|}{ Gluteus medius } \\
\hline Moisture & $70.62 \pm 2.02$ & $72.34 \pm 2.92$ & 0.512 \\
\hline Fat & $7.13 \pm 0.91$ & $3.08 \pm 0.33$ & $<0.001$ \\
\hline Protein & $21.02 \pm 1.03$ & $23.41 \pm 1.27$ & $<0.05$ \\
\hline Ash & $1.04 \pm 0.05$ & $1.11 \pm 0.04$ & 0.118 \\
\hline
\end{tabular}

\section{Results}

\subsection{Effect of the breed on proximate composition}

Proximate composition of Swallow Belly Mangalitsa and Swedish Landrace muscles is presented in Table 2. Compared to SL, both MA muscles had significantly higher fat content $(P<0.001)$. The other parameters did not significantly differ between groups, with the exception of the protein content of GM muscles, which was significantly higher in SL pork $(P<0.05)$.

\subsection{Effect of the breed on colour characteristics}

The $\mathrm{pH}$ value and the colour characteristics of LT and GM as a function of breed and time of storage are presented in Tables 2 and 3 respectively.

The $\mathrm{pH}$ of Longissimus dorsi (LD) and GM muscles was significantly higher in MA pigs than SL pigs $(P<0.05$ for LT; $P<0.01$ for GM). The relative content of Mb was significantly higher in the MA group of pigs for both muscles analysed $(P<0.01$ for LT; $P<0.001$ for GM). The relative content of $\mathrm{MbO}_{2}$ differed only for LT muscles $(P<0.001$ higher in the MA group of pigs), whilst MetMb content was found to be lower for LT muscles $(P<0.001)$ but higher for GM muscles $(P<0.05)$ in MA pigs. Swallow Belly Mangalitsa pigs had a significantly higher oxy / met (oxymyoglobin / metmyoglobin) ratio compared to Swedish Landrace pigs $\left(P<0.001\right.$ for LT; $P<0.05$ for GM) and lower $L^{*}$ values $(P<0.001$ for LT; $P<0.001$ for GM) for both muscles analysed. MA pigs had less yellow LT muscles, lower $b^{*}$ colour values $(P=0.010)$ and more red GM muscles, and higher $a^{*}$ colour values $(P<0.001)$. Chroma values differed significantly between breeds only for GM muscles and were higher in MA group $(P<0.001)$. No breed effect was registered with regard to the degree of redness $(P=0.058)$, chroma values for LT muscles, and the degree of yellowness 
Table 3. pH and colour parameters of LT muscles of Swallow Belly Mangalitsa (MA) and Swedish Landrace (SL) pigs during 6 days of vacuum storage.

\begin{tabular}{|c|c|c|c|c|c|c|c|c|c|}
\hline & \multicolumn{3}{|c|}{ MA } & \multicolumn{3}{|c|}{ SL } & \multicolumn{3}{|c|}{$P$ value } \\
\hline & 1 & 3 & 6 & 1 & 3 & 6 & Breed & Time & $\begin{array}{r}\text { Breed } \\
\times \text { time }\end{array}$ \\
\hline $\mathrm{pH}$ & $5.51 \pm 0.03$ & $5.41 \pm 0.08$ & $5.45 \pm 0.11$ & $5.47 \pm 0.03^{\mathrm{a}}$ & $5.28 \pm 0.02^{\mathrm{b}}$ & $5.34 \pm 0.02^{\mathrm{ab}}$ & $<0.05$ & $<0.01$ & 0.468 \\
\hline $\mathrm{Mb}$ & $1.42 \pm 0.24^{\mathrm{a}}$ & $1.34 \pm 0.14^{\mathrm{a}}$ & $1.25 \pm 0.09^{\mathrm{b}}$ & $1.27 \pm 0.05$ & $1.17 \pm 0.10$ & $1.23 \pm 0.10$ & $<0.01$ & $<0.05$ & 0.157 \\
\hline $\mathrm{MbO}_{2}$ & $3.24 \pm 0.89$ & $3.48 \pm 0.73$ & $3.43 \pm 0.80$ & $2.16 \pm 0.09$ & $2.03 \pm 0.17$ & $1.96 \pm 0.12$ & $<0.001$ & 0.957 & 0.673 \\
\hline MetMb & $0.66 \pm 0.12^{\mathrm{a}}$ & $0.77 \pm 0.08^{b}$ & $0.75 \pm 0.07^{b}$ & $0.79 \pm 0.04$ & $0.78 \pm 0.05$ & $0.84 \pm 0.05$ & $<0.001$ & $<0.05$ & 0.054 \\
\hline Oxy / met & $3.88 \pm 0.68^{\mathrm{a}}$ & $3.98 \pm 0.56^{\mathrm{b}}$ & $4.43 \pm 0.83^{b}$ & $2.67 \pm 0.26$ & $2.32 \pm 0.22$ & $2.24 \pm 0.12$ & $<0.001$ & $<0.05$ & 0.078 \\
\hline$L^{*}$ & $51.38 \pm 5.19$ & $50.65 \pm 5.61$ & $51.18 \pm 5.16$ & $61.30 \pm 1.36^{\mathrm{a}}$ & $57.33 \pm 1.28^{\mathrm{ab}}$ & $52.24 \pm 3.89^{b}$ & $<0.001$ & $<0.05$ & $<0.05$ \\
\hline$a^{*}$ & $13.15 \pm 2.84$ & $12.11 \pm 2.57$ & $12.25 \pm 2.69$ & $10.28 \pm 0.86$ & $11.09 \pm 0.78$ & $12.45 \pm 0.81$ & 0.058 & 0.593 & 0.151 \\
\hline$b^{*}$ & $7.22 \pm 2.00$ & $6.93 \pm 2.13$ & $7.12 \pm 2.09$ & $8.93 \pm 0.64$ & $8.11 \pm 1.07$ & $8.19 \pm 2.10$ & $<0.01$ & 0.653 & 0.856 \\
\hline$h$ & $28.57 \pm 5.23$ & $29.60 \pm 7.12$ & $29.95 \pm 5.69$ & $41.02 \pm 2.06^{\mathrm{a}}$ & $36.07 \pm 2.28^{\mathrm{ab}}$ & $32.89 \pm 6.22^{b}$ & $<0.001$ & $<0.05$ & $<0.05$ \\
\hline$C^{*}$ & $15.05 \pm 3.22$ & $14.05 \pm 2.90$ & $14.23 \pm 3.13$ & $13.62 \pm 0.96$ & $13.75 \pm 1.20$ & $14.97 \pm 1.55$ & 0.656 & 0.737 & 0.490 \\
\hline
\end{tabular}

a, b Means within the same row but without a common letter differ significantly at $P<0.050$

for GM muscles $(P=0.527)$. Additionally, hue angle values were significantly lower in MA pigs compared to SL pigs $(P<0.001$ for LT; $P<0.001$ for GM).

\subsection{Effect of the storage time on the colour characteristics}

The decline in the $\mathrm{pH}$ value of meat, during 6 days of vacuum storage, was more pronounced in SL pigs for both muscles $(P<0.01$ for LT; $P<0.05$ for GM). The $\mathrm{pH}$ values decrease after day 1 , and the differences are statistically significant between day 1 and day 3 in LT muscles as well as day 1 and the other two intervals of storage (day 3 and 6) in GM muscles. Additionally, the change in meat $\mathrm{pH}$ in MA pigs was milder and not significant during storage for both analysed muscles. In MA pigs, storage time significantly affected the relative content of $\mathrm{Mb}$ in meat, which decreased with time $(P<0.05$ for LT; $P<0.001$ for GM), while no significant effect was established for SL pork. The relative content of $\mathrm{MbO}_{2}$ significantly changed during storage only in GM muscles, it increased in MA and decreased in SL muscle $(P<0.005)$ after 3 days of storage. The $\mathrm{MbO}_{2}$ content of LT muscles of both groups was not changed during storage. MetMb content increased in LT muscles $(P<0.05)$ and decreased in GM muscles $(P<0.05)$ only in the MA group, with significant differences between day 1 and the other two intervals of storage (day 3 and 6). The oxy / met ratio increased significantly with time in MA pigs for both muscles $(P<0.05$ for LT; $P<0.05$ for GM) and decreased after 3 days of storage and remained unchanged till day 6 in SL pigs, but this was significant only for the GM muscle. CIE $L^{*} a^{*} b^{*} C^{*} h$ values of LT muscles did not change significantly in MA pigs, while in SL pigs, storage time affected decreasing lightness $(P<0.05)$ and hue angle values $(P<0.05)$. During refrigerator storage of vacuum-packed GM muscles, yellowness $(P<0.01)$ and hue angle values $(P<0.001)$ significantly increased in both groups of pigs. Additionally, $L^{*}$ values of GM muscle, as op- posed to LT muscles, significantly increased after 3 days of storage $(P<0.001)$ in the SL group. There was no significant effect of storage time on $a^{*}$ values of the muscles analysed in both groups of pigs ( $P=0.593$ for LT; $P=0.641$ for GM) and also on $b^{*}$ and $C^{*}$ for LT of SL pigs, and on $L^{*}$ and $C^{*}$ for GM of MA pigs and on $C^{*}$ for GM of SL pigs $(P>0.05)$.

\subsection{Effect of the breed and storage time interaction}

A two-way analysis of variance yielded a significant interaction between breed of pigs and storage time for $L^{*}$ values $(P<0.05$ for LT; $P<0.001$ for GM) and for hue angle values $(P<0.05$ for LT; $P<0.01$ for GM). No significant interactions between breed and time of storage were found for the $\mathrm{pH}$ value and colour stability parameters of LT muscles and for the $\mathrm{pH}$ value and $a^{*}, b^{*}$ and $C^{*}$ parameters of GM muscles $(P>0.05)$. Additionally, there was an interaction between breed and storage time for the relative content of $\mathrm{Mb}$ pigments of GM muscles $\left(P<0.05\right.$ for $\mathrm{MbO}_{2}$ and $P<0.05$ for MetMb).

\section{Discussion}

\subsection{Effect of the breed on proximate composition}

The established high fat content of MA pork is characteristic for this pig breed (Petrović et al., 2010, 2014; Stanišić et al., 2013; Tomović et al., 2014). This higher fat content or marbling can have a great impact on the quality characteristics of meat and meat products (Gandemer, 2002). In addition, all pigs were determined to be non-carriers of the unfavourable RYRI alleles by polymerase chain reaction restriction endonuclease fragment length polymorphism (PCRRFLP) genotyping by the method described in Stanišić et al. (2012). 
Table 4. $\mathrm{pH}$ and colour parameters of GM muscles of Swallow Belly Mangalitsa (MA) and Swedish Landrace (SL) pigs during 6 days of vacuum storage.

\begin{tabular}{|c|c|c|c|c|c|c|c|c|c|}
\hline & \multicolumn{3}{|c|}{ MA } & \multicolumn{3}{|c|}{ SL } & \multicolumn{3}{|c|}{$P$ value } \\
\hline & 1 & 3 & 6 & 1 & 3 & 6 & Breed & Time & $\begin{array}{l}\text { Breed } \\
\times \text { time }\end{array}$ \\
\hline $\mathrm{pH}$ & $5.56 \pm 0.03$ & $5.62 \pm 0.03$ & $5.61 \pm 0.07$ & $5.65 \pm 0.04^{\mathrm{a}}$ & $5.38 \pm 0.04^{b}$ & $5.40 \pm 0.10^{\mathrm{b}}$ & $<0.01$ & $<0.05$ & 0.211 \\
\hline $\mathrm{Mb}$ & $1.64 \pm 0.08^{a}$ & $1.44 \pm 0.09^{b}$ & $1.45 \pm 0.07^{b}$ & $1.45 \pm 0.05$ & $1.43 \pm 0.08$ & $1.39 \pm 0.05$ & $<0.001$ & $<0.001$ & 0.452 \\
\hline $\mathrm{MbO}_{2}$ & $3.24 \pm 0.20^{\mathrm{a}}$ & $3.78 \pm 0.37^{\mathrm{a}}$ & $4.46 \pm 0.57^{b}$ & $4.48 \pm 0.33^{\mathrm{a}}$ & $4.28 \pm 1.06^{\mathrm{a}}$ & $3.57 \pm 0.27^{b}$ & 0.416 & $<0.05$ & $<0.05$ \\
\hline MetMb & $0.89 \pm 0.02^{\mathrm{a}}$ & $0.68 \pm 0.04^{b}$ & $0.70 \pm 0.05^{b}$ & $0.77 \pm 0.04$ & $0.72 \pm 0.05$ & $0.73 \pm 0.04$ & $<0.05$ & $<0.05$ & $<0.05$ \\
\hline Oxy / met & $3.82 \pm 0.28^{\mathrm{a}}$ & $4.43 \pm 0.41^{b}$ & $5.28 \pm 0.62^{\mathrm{c}}$ & $4.98 \pm 0.49^{\mathrm{a}}$ & $4.38 \pm 0.73^{\mathrm{b}}$ & $3.96 \pm 0.31^{\mathrm{c}}$ & $<0.05$ & $<0.05$ & 0.670 \\
\hline$L^{*}$ & $40.17 \pm 2.50$ & $40.08 \pm 2.27$ & $40.74 \pm 2.11$ & $44.24 \pm 2.40^{\mathrm{a}}$ & $45.55 \pm 2.02^{\mathrm{a}}$ & $53.19 \pm 7.54^{b}$ & $<0.001$ & $<0.001$ & $<0.001$ \\
\hline$a^{*}$ & $18.80 \pm 1.55$ & $19.00 \pm 1.61$ & $19.50 \pm 1.65$ & $14.99 \pm 2.11$ & $14.12 \pm 1.83$ & $13.29 \pm 3.22$ & $<0.001$ & 0.641 & 0.104 \\
\hline$b^{*}$ & $6.98 \pm 1.11^{\mathrm{a}}$ & $7.53 \pm 1.62^{\mathrm{ab}}$ & $8.18 \pm 1.65^{\mathrm{b}}$ & $7.11 \pm 0.71^{\mathrm{a}}$ & $7.66 \pm 0.97^{\mathrm{ab}}$ & $8.48 \pm 0.93^{\mathrm{b}}$ & 0.527 & $<0.01$ & 0.970 \\
\hline$h$ & $20.28 \pm 2.09^{\mathrm{a}}$ & $21.39 \pm 2.68^{a b}$ & $22.56 \pm 2.82^{b}$ & $25.55 \pm 2.10^{\mathrm{a}}$ & $28.53 \pm 1.41^{\mathrm{b}}$ & $33.37 \pm 6.16^{\mathrm{c}}$ & $<0.001$ & $<0.001$ & $<0.01$ \\
\hline$C^{*}$ & $20.07 \pm 1.76$ & $20.46 \pm 2.07$ & $21.17 \pm 2.09$ & $16.60 \pm 2.15$ & $16.07 \pm 2.03$ & $15.84 \pm 2.95$ & $<0.001$ & 0.936 & 0.302 \\
\hline
\end{tabular}

a,b,c Means within the same row but without a common letter differ significantly at $P<0.050$.

\subsection{Effect of the breed on the colour characteristics}

The ultimate $\mathrm{pH}$ value, in all analysed muscles, was within the characteristic range for normal $\mathrm{pH}_{24 \mathrm{~h}}$ pork, i.e. from 5.3 to 5.8 (Honikel, 1999). The higher $\mathrm{pH}$ value of meat of autochthonous pigs is in agreement with the research in Kasprzyk et al. (2015) and may be associated with better water holding capacity and a darker colour of meat (Lawrie and Ledward, 2006).

Most of the differences in the colour of the meat surface arise from the chemical state of the myoglobin molecules (Lawrie and Ledward, 2006). Research shows that a high level of muscular activity (i.e. free-range rearing) induces more myoglobin (Tomović et al., 2014), which is consistent with this study, since the MA group of pigs had a significantly higher relative content of $\mathrm{Mb}$ (Table 3 and 4). The higher MetMb content in LT muscles of SL pork and in GM muscles of MA pork indicates a higher tendency towards discolouration and, according to Zhu and Brewer (1998), a lower MetMb-reducing capacity. However, it is not known whether the above distinction between muscles can be explained by different activity of MetMb accumulation.

Pure forms of $\mathrm{MbO}_{2}$ and MetMb have oxy / met values of 5 and 1 respectively (Hunt et al., 1991) and studies suggest that oxy / met values greater than or equal to 3.5 were considered to be acceptable (red) and those less than 3.5 unacceptable (brown) in colour (Morrissey et al., 2008). In this research, the oxy / met values were greater than 3.5 except for LT muscles of SL pigs (approx. 2.5), which is lower than the above recommendations (Table 3 and 4). The significantly higher oxy / met ratio of MA pork could mean a better colour acceptability of this meat by consumers.

Lightness and yellowness are shown to be negatively correlated to the relative content of $\mathrm{Mb}$ and positively correlated to the relative content of $\mathrm{MbO}_{2}$ (Lindahl et al., 2001). Based on the instrumental colour measurements in the present study, it can be stated that one prominent characteristic of
Swallow Belly Mangalitsa muscles is darker colour (Table 3 and 4). These results are in agreement with results reported for Longissimus dorsi by Cava et al. (2003) and Estévez et al. (2003) for Iberian pigs; Peinado et al. (2004), Poto et al. (2007) and Galián et al. (2009) for Chato Murciano pigs; Pugliese et al. (2004, 2005) for Nero Siciliano and Cinta Senese pigs; and Tomović et al. (2014) for Swallow Belly Mangalitsa pigs. The reasons for this are probably the lower $\mathrm{pH}$ values of SL pork, influencing more "open" protein structure, which give the meat paler appearance (Karlsson et al., 1993; Wiegand et al., 2001), and a higher Mb content of MA pork.

Research by Lindahl et al. (2006) on Landrace and Duroc crossbreeds indicates that a higher $\mathrm{Mb}$ content results in a darker and less yellow colour of meat. In the previous study of Stanišić et al. (2013), the share of yellow colour $\left(b^{*}\right)$ of LT muscles was significantly higher in the Landrace compared to the Swallow Belly Mangalitsa pig breed, all fed with concentrated commercial feed and kept in an indoor production system. Regarding this, in the current research, lower yellowness of the LT muscles of MA meat (Table 3) was not due to the free-range management system. However, further research is needed to confirm this.

\subsection{Effect of the storage time on the colour characteristics}

Storage of pork in vacuum has been reported to increase the blooming ability of the meat due to a progressive inactivation of the inherent oxygen-consuming enzyme systems (Ledward, 1992) without a substantial weakening of the MetMbreducing ability (Bekhit and Faustman, 2005). The present study showed no effect of ageing on LT myoglobin oxidation in SL pigs (Table 3), which is in agreement with findings of Lindahl et al. (2006). By contrast, in the MA group, cold storage had a significant effect on reducing the relative content of $\mathrm{Mb}$ and increasing the relative content of MetMb and the 
oxy / met ratio in meat (Table 3 and 4). These findings indicate a more rapid colour fading in aged Swallow Belly Mangalitsa pork compared with pork of the commercial Swedish Landrace breed. Additionally, the decrease in the oxy / met ratio in meat of SL pigs was probably a consequence of decreasing the oxidised form of myoglobin during storage.

Published research papers are not conclusive regarding the effects of storage time on tristimulus colour values (CIE $L^{*} a^{*} b^{*}$ ) of vacuum-packed pork. Smith et al. (1974) found that Longissimus dorsi muscle had become lighter after 28 days of storage, whereas Hall et al. (1980) and Schluter et al. (1994) found no differences in colour changes in M. longissimus dorsi during storage. Conversely, Mendonca et al. (1989) reported that $L^{*}$ and $a^{*}$ values of LT muscles decreased during 4 weeks storage, indicating that pork colour became darker and less red. In the research of Lindahl et al. (2006), cold storage for 8 days increased lightness, redness and yellowness of Landrace and Duroc pork, whereas Apple et al. (2002) found increased lightness, decreased yellowness, but no effect on redness after 3 weeks of vacuum storage. Rosenvold and Andersen (2003) reported higher redness and yellowness but no difference in lightness after 8 days of vacuum storage of pork. In the present study, cold storage had a greater effect on changes in CIE $L * a * b *$ values of LT and GM muscles (Table 4) of the SL group of pigs. The change in the $a^{*}, b^{*}$ and $C^{*}$ values as a function of storage time can be due to the changes in myoglobin forms in the meat (Johansson, 1989; Lindahl et al., 2001). The absence of a storage effect on the redness of analysed muscles, of both groups of pigs, is in disagreement with research by Zhu et al. (2001) and Frederick et al. (2004) according to which storage of vacuum-packaged pork results in higher redness ( $a^{*}$ values).

\subsection{Effect of the breed and the storage time interaction}

Storage time significantly changed the $L^{*}$ and $h$ value of SL pork (decreased for LT and increased for GM), and there was also a significant interaction between breed and storage time, arising from the fact that the effect of storage was greatest at day 6 , when the change in lightness and hue values was highest compared with day 1 . The significant interaction between breed and storage time for the relative content of $\mathrm{Mb}$ pigments of GM muscles (Table 4) reflects the result that GM muscles had opposite changes in $\mathrm{MbO}_{2}$ and MetMb in MA and SL group of pigs during 6 days of storage. This would suggest that the effect of the breed variable was greater at the end of the storage time for the above-mentioned parameters.

In conclusion, the meat from the free-range Swallow Bellys Mangalitsa pigs had better colour stability for 6 days of refrigerator vacuum storage compared to the meat from the modern pig breed, and it is recommended to age this meat if it is intended to be marketed as high-quality pork.
Acknowledgements. This paper is a result of the research within the project TR31081, financed by the Ministry of Education, Science and Technological Development, Serbia.

Edited by: S. Maak

Reviewed by: V. Tomovic, T. Popova, and S. Lilic

\section{References}

Apple, J. K., Davis, J. R., Rakes, L. K., Maxwell, C. V., Stivarius, M. R., and Pohlman, F. W.: Effects of dietary magnesium and duration of refrigerated storage on the quality of vacuum-packaged, boneless pork loins, Meat Sci., 57, 43-53, 2001.

Apple, J. K., Stivarius, M. R., Reiman, J. D., Rakes, L. K., and Maxwell, C. V.: Halothane-genotype and duration of refrigerated storage effects on the quality of vaccum-packaged pork loins, J. Muscle Foods, 13, 103-122, 2002.

Barton-Gade, P.: Welfare of animal production in intensive and organic systems with special reference to Danish organic pig production, Meat Sci., 62, 353-358, 2002.

Bekhit, A. E. D. and Faustman, C.: Metmyoglobin reducing activity. A review, Meat Sci., 71, 407-439, 2005.

Brewer, M. S., Zhu, L. G., Bidner, B., Meisinger, D. J., and McKeith, F. K.: Measuring pork color: effects of bloom time, muscle, $\mathrm{pH}$ and relationship to instrumental parameters, Meat Sci., 57, 169-176, 2001.

Brewer, M. S., Sosnicki, A., Field, B., Hankes, R., Ryan, K. J., Zhu, L. G., and McKeith, F. K.: Enhancement effects on quality characteristics of pork derived from pigs of various commercial genetic backgrounds, J. Food Sci., 69, 5-10, 2004.

Cava, R., Estévez, M., Ruiz, J., and Morcuende, D.: Physicochemical characteristics of three muscles from free-range reared Iberian slaughter at $90 \mathrm{~kg}$ live weight, Meat Sci., 63, 533-541, 2003.

CIE: International Commission on Illumination, Colorimetry: Official Recommendation of the International Commission on Illumination, Publication CIE No. (E-1.31), Bureau Central de la CIE, Paris, France, 1976.

DAD-IS: Domestic animal diversity information system, available at: http://dad.fao.org/ (last access: 20 October 2015), 2003.

Edwards, D. B., Bates, R. O., and Osburn, W. N.: Evaluation of Duroc- vs. Pietrain-sired pigs for carcass and meat quality measures, J. Anim. Sci., 81, 1895-1899, 2003.

Egerszegi, I., Rátky, J., Solti, L., and Brüssow K. P.: Mangalica - an indigenous swine breed from Hungary (Review), Arch. Tierzucht, 46, 245-256, 2003.

Estévez, M., Morcuende, D., and Cava R.: Physico-chemical characteristics of $M$. Longissimus dorsi from three lines of free-range reared Iberian pigs slaughtered at $90 \mathrm{~kg}$ liveweight and commercial pigs: a comparative study, Meat Sci., 64, 499-506, 2003.

Frederick, B. R., van Heugten, E., and See, M. T.: Timing of magnesium supplementation administered through drinking water to improve fresh and stored pork quality, J. Anim. Sci., 82, 14541460, 2004.

Galián, M., Poto, A., and Peinado, B.: Carcass and meat quality traits of the Chato Murciano pig slaughtered at different weights, Livest. Sci., 124, 314-320, 2009. 
Gandemer, G.: Lipids in muscles and adipose tissues, changes during processing and sensory properties of meat products, Meat Sci., 62, 309-321, 2002.

Hall, L. C., Smith, G. C., Dill, C. W., Carpenter, Z. L., and Vanderzant, C.: Physical and sensory characteristics of pork loins stored in vacuum or modified atmosphere packages, J. Food Protect., 43, 272-276, 1980.

Honikel, K. O.: Biochemical and physico-chemical characteristics of meat quality, Tehnologija mesa, 40, 105-123, 1999.

Hunt, M. C., Acton, J. C., Benedict, R. C., Calkins, C. R., Cornforth, D. P., Jeremiah, L. E., Olson, D. G., Salm, C. P., Savell, J. W., and Shivas, S. D.: Guidelines for meat colour evaluation, Proceedings of 44th Annual Reciprocal Meat Conference. American Meat Science Association and National Live Stock and Meat Board, Manhattan, USA, 1-17, 1991.

ISO 1443: Meat and meat products - Determination of total fat content, International Organisation for Standardisation, Geneva, Switzerland, 1973.

ISO 937: Meat and meat products - Determination of nitrogen content (reference method), International Organisation for Standardisation, Geneva, Switzerland, 1978.

ISO 1442: Meat and meat products - Determination of moisture content (Reference method), International Organisation for Standardisation, Geneva, Switzerland, 1997.

ISO 936: Meat and meat products - Determination of ash content (reference method), International Organisation for Standardisation, Geneva, Switzerland, 1998.

ISO 2917: Meat and meat products - Measurement of pH (Reference method), International Organisation for Standardisation, Geneva, Switzerland, 1999.

Johansson, G.: Relationships between different colour parameters from reflectance measurements of bovine muscles, In Proceedings of the 35th international congress of meat science and technology, 20-25 August 1989, Copenhagen, Denmark, 601-607, 1989.

Karlsson, A., Enfalt, A. C., Essen-Gustavsson, B., Lundstrom, K., Rydhmer, L., and Stern, S.: Muscle histochemical and biochemical properties in relation to meat quality during selection for increased lean tissue growth rate in pigs, J. Anim. Sci., 71, 930938, 1993.

Kasprzyk, A., Tyra, M., and Babicz, M.: Fatty acid profile of pork from a local and a commercial breed, Arch. Anim. Breed., 58, 379-385, 2015.

Kijlstra, A., Meerburg, B. G., and Bos, A. P.: Food safety in freerange and organic livestock systems: risk management and responsibility, J. Food Protect, 72, 2629-2637, 2009.

Lawrie, R. A. and Ledward, D. A.: Lawrie's meat science (7th ed.), Woodhead Publishing Ltd. and CRC Press LLC, Cambridge, UK, 2006.

Ledward, D.: Colour of raw and cooked meat, Roy. Soc. Ch., 106, p. $128,1992$.

Lindahl, G., Lundström, K., and Tornberg, E.: Contribution of pigment content, myoglobin forms and internal reflectance to the colour of pork loin and ham from pure breed pigs, Meat Sci., 59, 141-151, 2001.

Lindahl, G., Henckel, P., Karlsson, A. H., and Andersen, H. J.: Significance of early postmortem temperature and $\mathrm{pH}$ decline on colour characteristics of pork loin from different crossbreeds, Meat Sci., 72, 613-623, 2006.
Mancini, R. A. and Hunt, M. C.: Current research in meat color, Meat Sci., 71, 100-121, 2005.

Mancini, R. A., Hunt, M. C., and Kropf, D. H.: Reflectance at $610 \mathrm{~nm}$ estimates oxymyoglobin content on the surface of ground beef, Meat Sci., 64, 157-162, 2003.

Mendonca, A. F., Molins, R. A., Kraft, A. A., and Walker, H. W.: Microbiological, chemical, and physical changes in fresh, vacuum-packaged pork treated with organic acids and salts, J. Food Sci., 54, 18-21, 1989.

Miao, Z. H., Glatz, P. C., and Ru, Y. J.: Review of production, husbandry and sustainability of free-range pig production systems, Asian Austral. J. Anim., 17, 1615-1634, 2004.

Morrissey, E. R., Jacob, R. H., and Pluske, J. M.: Perception of red brown colour by consumers, Proceeding of the 54th International Congress of Meat science and Technology, Session 9.7, 10-15 August 2008, Cape Town, South Africa, 1-3, 2008.

Peinado, B., Poto, A., Gil, F., and López, G.: Characteristics of the carcass and meat of the Chato Murciano pig, Livest. Prod. Sci., 90, 285-292, 2004.

Petrović, M., Mijatović, M., Radović, Č., Radojković, D., Parunović, N., and Stanišić, N.: Genetic resources in pig breeding - carcass and meat quality traits of Moravka and Mangalitsa breeds, Proceedings of the 1st Conference of the Balkan Network for the Animal Reproduction Biotechnology, 18-19 February 2009, Sofia, Bulgaria, p. 14, 2009.

Petrović, M., Radović, Č., Parunović, N., Mijatović, M., Radojković, D., Aleksić, S., Stanišić, N., and Popovac, M.: Quality traits of carcass sides and meat of Moravka and Mangalitsa pig breeds, Biotech. Anim. Husb., 26, 21-27, 2010.

Petrović, M., Wähner, M., Radović, Č., Radojković, D., Parunović, N., Savić, R., and Brkić, N.: Fatty acid profile of m. longissimus dorsi of Mangalitsa and Moravka pig breeds, Arch. Tierzucht, 57, 1-12, 2014.

Poto, A., Galián, M., and Peinado, B.: Chato Murciano pig and its crosses with Iberian and Large White pigs, reared outdoors. Comparative study of the carcass and meat characteristics, Livest. Sci., 111, 96-103, 2007.

Pugliese, C., Calagna, G., Chiofalo, V., Moretti, V., Margiotta, S., Franci, O., and Gandini, G.: Comparison of the performances of Nero Siciliano pigs reared indoors and outdoors. 2. Joints composition, meat and fat traits, Meat Sci., 68, 523-528, 2004.

Pugliese, C., Bozzi, R., Campodoni, G., Acciaioli, A., Franci, O., and Gandini, G.: Performance of Cinta Senese pigs reared outdoors and indoors. 1. Meat and subcutaneous fat characteristics, Meat Sci., 69, 459-464, 2005.

Putnam, P. A.: Animal Breeds, Handbook of Animal Science, Academic Press Inc., San Diego, CA, USA and London, UK, 107149, 1991.

Rosenvold, K. and Andersen, H. J.: The significance of preslaughter stress and diet on colour and colour stability of pork, Meat Sci., 63, 199-209, 2003.

Sales, J. and Koukolová, V.: Dietary vitamin E and lipid and color stability of beef and pork: Modeling of relationships, J. Anim. Sci., 89, 2836-2848, 2011.

Schluter, A. R., Miller, M. F., Jones, D. K., Meade, M. K., Ramsey, C. B., and Patterson, L. L.: Effects of distribution packaging method and storage time on the physical properties and retail display characteristics of pork, Meat Sci., 37, 257-269, 1994. 
Shapiro, S. S. and Wilk M.: An analyses of variance test for normality (complete samples), Biometrika, 52, 591-611, 1965.

Smith, G. C., Rape, S. W., Motycka, R. R., and Carpenter, Z. L.: Packaging systems for extending the storage life of pork cuts, J. Food Sci., 39, 1140-1144, 1974.

SPSS: IBM SPSS Statistics 20. 1 New Orchard Road, Armonk, IBM Corporation, New York, USA, 2010.

Stanišić, N., Aleksić, S., Di, L., Stanimirović, Z., Zhenhua, G., Petrović, M., Delić, N., Radović, Č., Parunović, N., and Gogić, M.: Porcine stress syndrome (PSS) in Mangalitsa pigs, Biotech. Anim. Husb., 28, 873-878, 2012.

Stanišić, N., Petrović, M., Parunović, N., Lilić, S., Radović, Č., Gogić, M., and Petričević, M.: Physicochemical properties of meat from three different pig breeds, Proceedings of the 57th International Meat Industry Conference, 10-12 June 2013, Belgrade, Serbia, 190-193, 2013.
Tomović, V. M., Žlender, B. A., Jokanović, M. R., Tomović, M. M., Šojić, B. V., Škaljac, S. B., Kevrešan, Ž. S., Tasić, T. A., Ikonić, P. M., and Šošo, M. M.: Sensory, physical and chemical characteristics of meat from freerange reared Swallow-belly Mangulica pigs, J. Anim. Plant Sci., 24, 704-713, 2014.

Wiegand, B. R., Parrish Jr., F. C., Swan, J. E., Larsen, S. T., and Baas, T. J.: Conjugated linoleic acid improves feed efficiency, decreases subcutaneous fat, and improves certain aspects of meat quality in stress-genotype pigs, J. Anim. Sci., 79, 2187-2195, 2001.

Zhu, L. G. and Brewer, M. S.: Metmyoglobin reducing capacity of fresh normal, PSE, and DFD pork during retail display, J. Food Sci., 63, 390-393, 1998.

Zhu, L. G., Bidner, B., and Brewer, M. S.: Postmortem pH, muscle, and refrigerated storage effects on ability of vacuum-packaged pork to bloom, J. Food Sci., 66, 1230-1235, 2001. 